\title{
The impact of simple leading up games accompanied by music on some physical and skillful variables in basketball for the educable mentally disabled.
}

\section{"Dr/ Adel Mohammed Ramadan}

Introduction and research pr oblem:

The indicators of nations and civilization progress and their upgrading are associated to a large extent of attention with different categories of generations. So, the attention to people with special needs of all communities is considered the most important criterio for judging its progress and development.

The prospective of societies in the present age has changed to the disable people. So, they now receive special care in many areas, including the sports field, taking into account their circumstances and physical potential. (34: 28, 29)

The practice of sports activities is considered of paramount importance to physical disabled as they qualify them to bear the burden of day life, satisfy their selves and develop their functional and psychological aspects. (24: 39)

So, starting to pay attention to the learning and training mentally disabled people through practice of various forms of sports, where the nature of the practice is varied according the interests and wishes of the disabled. Amal Mahrous (2002) pointed out to the need of mentally disabled to learn practice of swimming sport, meanwhile Ahmed Amir (2010) points out to learn them through karate. But both Amir Rafat (2013), Mohamed Abdel Fattah (2010), Mohamed Fathi (2004), Magda Ibrahim (2000), agreed that the necessity of their learning through a motor program aiming to development of physical fitness and basic natural skills, and both of Omima El shoobky (1994), Zozo Hamid (1999), Amal Mohammed Al -

"Assistant Professor, of theories and applications of sports and racket games Dep. , Faculty of Physical Education for Boys and Girls , Port Said University. 
Attar (2000), Mohammed Abu Zeid (2004) and Mohamed Badawi (2004) points out to necessity of learning mentally disabled through using simple leading up games and popular games, because of its their positive effect on physical fitness and motor skills. (11), (6), (13), (22), (23), (20), (33), (40), (10), (25), (28).

\section{Ellen Wadih}

(1996)

clarified that simple leading up games are considered one of the sports activities that practiced for both of all ages and sexes and are familiar to interests and wishes of the mentally disabled (16:24).

Amin Al Khuli and Jamal AlShafy (2009) confirme $\mathrm{d}$ that simple leading up games are considered the best games for mentally disabled, where they practice them according to their, mental and skillful level , simplified nature and are considered an a approach to disabled as for the speed of acquisition of basic skills associated with sports games. Through simplified games the player can practice the game

skills without boredom and improve their skills, and increase their attention and positive performance compared to (12:140,141).

traditional

drills

Through the reference survey of the studies that dealt with the simple leading up games, it became clear how important these games are and their positive role in the development of physical fitness and basic skills in various sports activities. (19), (14), (15), (33), (36), (37), (40), (4), (8), (17), (28), (29), (25), (30).

Also, in addition to the lack of researches conducted in basketball field of mentally disabled persons, where they did not have enough attention in that area, and through the experience of the researcher as former player and a coach, as well as his following up the republic championships, he noted the weakness of the physical level and skills of the players, in addition to their irregular training and feeling boring and monotonous during the training period. Therefore, the researcher conducted this research to identify the effect of simple leading up games accompanied by music on some physical and skillful variables in basketball for the educable mentally disabled. 
Research aim:

The research aims to develop the physical and skillful variables in basketball for educable mentally disabled people through using simple leading up games accompanied by music.

\section{Research hypotheses:}

1. There are statistically significant differences between pre and post measurements in some physical variables for educable mentally disabled persons

2. There are statistically significant differences between pre and post measurements in some skillful variables for educable mentally disabled people .

Research terminology:

Intellectual disability:

They are people with mental limited ability and educable of degree that makes them unable to adjust with surrounding environment and their colleagues around them , and the proportion of their

intelligence, ranging between (50-70), and mental age of (712 years) and can be compatible with minimal control $(35: 45),(1: 16)$.

Educable (Learnable):
They are people whose their progressive proportion is slow as for well and their intelligence proportion $\quad(50-$ 70), and in old age they can be in an economic and social independent status and are requiring some kind of derived programs towards social adjustment and vocational guidance and mental age ranges between (6-9 years), and can reach to third and fourth primary grade (31:35), (21:58).

\section{Research procedures:} Research methodology:

The researcher used the experimental method becau se of the nature of the research through the experimental design of one group by pre and post measurements.

\section{Research sample:}

Sample was selected purposively from team of youth popular arena in Port Said and who are registered in Egyptian Federation of mental disability of ages stage from (16-18) years old $(n=12)$, of players of aged5 intelligence proportion ranged between (50-70 degrees) according to data for female players belonging to Egyptian Federation of mental 
disability through Stanford Binet test of intelligence.

The researcher conducted homogeneity among individuals in the growth rates (Age, height, weight, training age), intelligence, physical and skillful variables, table (1).

\section{Table (1)}

Arithmetic mean, median, standard deviation, and skewedness coefficient of growth rates, training age, intelligence, physical and skillful variables of research. $\mathrm{N}=12$

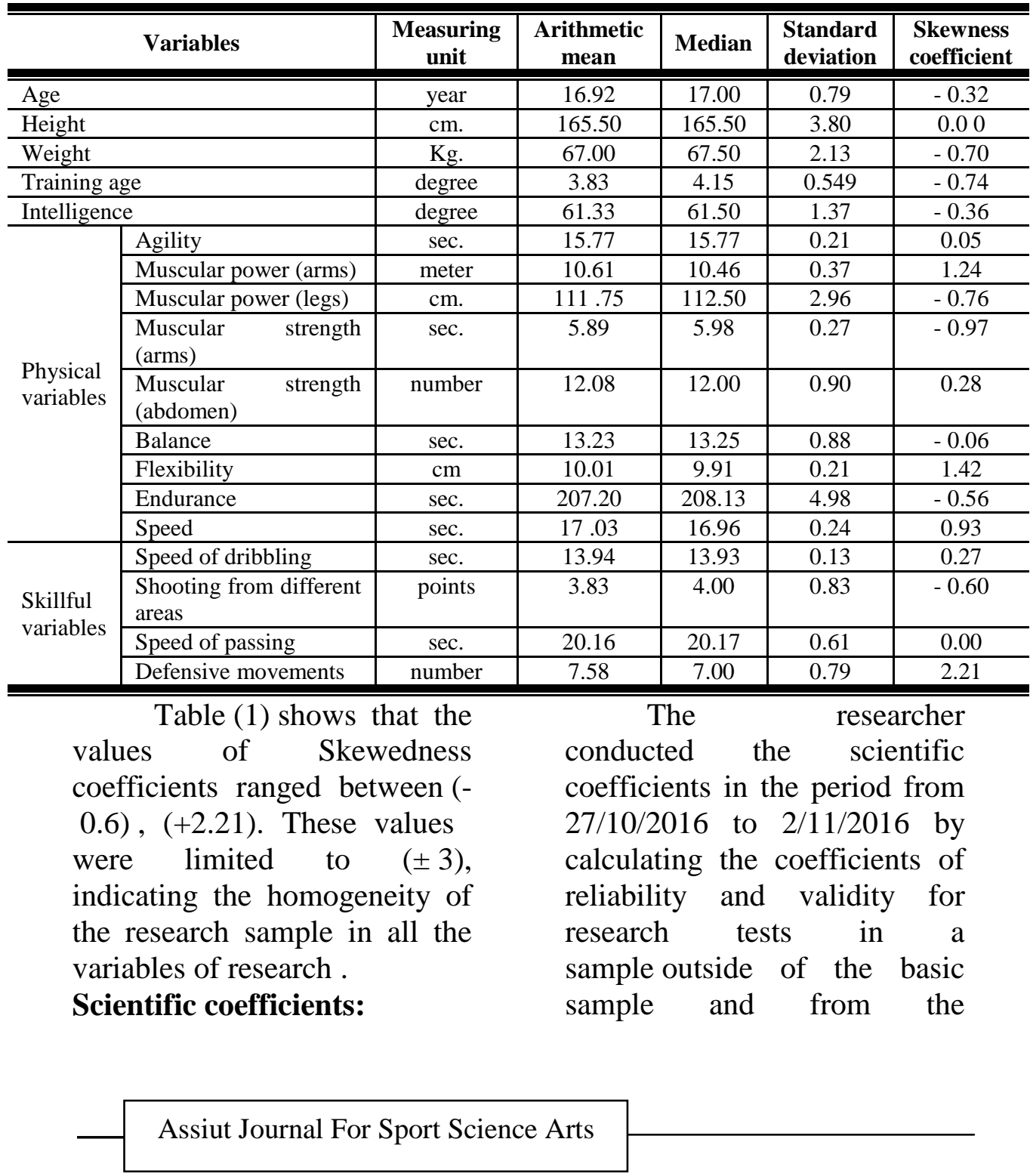


same research society

of (10) female players.

\section{Calculating \\ reliability coefficients:}

The researcher calculated the reliability coefficients of the research tests by finding the correlation coefficient " $\mathrm{r}$ " by applying the tests and reapplying them after a week time interval, as shown in table (2).

Table (2)

Reliability and validity coefficients of Physical and skillful tests (of research) $\mathrm{N}=12$

\begin{tabular}{|c|c|c|c|c|c|c|c|c|}
\hline & Variables & $\begin{array}{l}\text { Measuring } \\
\text { unit }\end{array}$ & $\mathbf{X} 1$ & $\mathbf{X} 2$ & $\begin{array}{l}\text { Sum } \\
\text { of } F\end{array}$ & $\begin{array}{l}\text { Sum } \\
\text { of } F^{2}\end{array}$ & $\begin{array}{c}\text { Value of } \\
(\mathbf{r}) \\
\text { calculated }\end{array}$ & $\begin{array}{c}\text { Self } \\
\text { validity }\end{array}$ \\
\hline \multirow{9}{*}{$\begin{array}{l}\text { Physical } \\
\text { variables }\end{array}$} & Agility & sec. & 14.47 & 14.44 & zero & 3 & 0.99 & 0.99 \\
\hline & $\begin{array}{ll}\begin{array}{l}\text { Muscular } \\
\text { (arms) }\end{array} & \text { power } \\
\end{array}$ & meter & 9.46 & 9.46 & zero & 4.5 & 0.98 & 0.99 \\
\hline & $\begin{array}{ll}\begin{array}{l}\text { Muscular } \\
\text { (legs) }\end{array} & \text { power } \\
\end{array}$ & $\mathrm{cm}$. & 106.75 & 106.00 & zero & 48.00 & 0.83 & 0.91 \\
\hline & $\begin{array}{l}\text { Muscular strength } \\
\text { (arms) }\end{array}$ & sec. & 5.59 & 5.57 & zero & 4 & 0.99 & 0.99 \\
\hline & $\begin{array}{ll}\begin{array}{l}\text { Muscular } \\
\text { (abdomen) }\end{array} & \text { strength } \\
\end{array}$ & number & 14.58 & 13.92 & zero & 47.5 & 0.83 & 0.91 \\
\hline & Balance & sec. & 12.18 & 12.08 & zero & 15.5 & 0.95 & 0.97 \\
\hline & Flexibility & $\mathrm{cm}$ & 8.95 & 8.70 & zero & 42 & 0.85 & 0.92 \\
\hline & Endurance & sec. & 217.25 & 215.17 & zero & 51 & 0.82 & 0.91 \\
\hline & Speed & sec. & 18.33 & 18.28 & zero & 16.5 & 0.94 & 0.97 \\
\hline \multirow{4}{*}{$\begin{array}{l}\text { Skillful } \\
\text { variables }\end{array}$} & Speed of dribbling & sec. & 14.76 & 14.76 & zero & 16.5 & 0.94 & 0.97 \\
\hline & $\begin{array}{ll}\begin{array}{l}\text { Shooting } \\
\text { different areas }\end{array} & \text { from } \\
\end{array}$ & points & 2.83 & 2.58 & zero & 50.00 & 0.83 & 0.91 \\
\hline & Speed of passing & sec. & 21.21 & 21.15 & zero & 8.50 & 0.97 & 0.99 \\
\hline & Defensive movements & number & 6.58 & 6.42 & zero & 33.00 & 0.88 & 0.94 \\
\hline
\end{tabular}

Table (2) shows that there is a statistically significant correlation at $(0,05)$ for the first application and second one in the physical and skillful variables of research. The calculated value of $(\mathrm{r})$ ranged between (0.83 - 0.99), and It is greater than value of (r) table, indicating the reliability of all the physical and skillful tests of research.

\section{Calculating the validity coefficient:}

The researcher calculated the validity coefficient through selfvalidity by the square root of reliability, where the values of validity coefficient ranged between 
(0.91 - 0.99). It indicates that the validity of all physical and skillful tests of research, as shown in table (2).

Tests used in the research:

The researcher conducted the referenced survey of the scientific references and related studies in the field of basketball, added to researches that dealt with educable intellectual disabilities in order to determine the most important tests that measure the physical and skillful variables in basketball of research, as follows, appendix (2).

\section{Tests of physical variables:}

The researcher used physical fitness test battery of American Association of the Mentally Disability (A.A.M.D) for age of (8-18) years, and it includes tests of measuring agility, muscular power (arms), muscular power (legs), muscular strength (arms and shoulder), muscular strength (abdomen), flexibility, balance, speed, cardio respiratory endurance (38:107), (13:98).

Tests for skillful variables:

1- Speed of dribbling around obstacles test $(24: 176,177)$, $(22,62)$.
2- Shooting from different areas test (5: 73).

3- Speed of passing test (5: 74).

4- Feet movements test $(7: 98)$

\section{Pilot studies:}

The

researcher

conducted pilot studies on a sample, outside of the basic research and from the same research community, which included (5) female players in the period from $24 / 10 / 2016$ to 2/11/2016 in order to:

1. Ensure the validity of the devices and tools used in the research.

2. Ensure that tests are suitable for level and abilities of research sample.

3. Conduct scientific coefficients (reliability and validity) for research tests.

\section{Basis of}

\section{the training program:}

1. The program should achieve the objectives for which it was set.

2. To suit the abilities of the mentally disabled people.

3. Taking into consideration the gradualism of drills used from easy to difficult and from simple to complex.

4. Be flexible and allow modification at any time. 
5. Taking into consideration individual differences among sample members.

6. Avoid any kind of punishment with the use of praise during performance.

7. Taking into consideration the continuity factor in the application of the program without any interruption from training.

Content of training program: The content of the training program has been determined through procedural steps as follows:

- The researcher reviewed the surveys of studies related to the field of basketball, as well as studies of educable mentally disabled, added to the studies that have been applied

in the field of simple leading up games, in order to determine the percentage and temporal distribution of training program, as shown in table (5), appendix (1).

- The training program lasted (10) weeks, and included physical, skillful and tactical preparation, where

the percentage and temporal distribution of program content were gradually set over (10) weeks, according to objectives every week. (22), (29), (42), (24), (33), (39), (11), (7), (2), (5), (8), (33), (41), (42), (14), (15), (10), (43), (44), (13), (6), (45), (30), (4).

- The training program consists of (30) training units, with (3) training units per week and of (90 min.) to training unit. Thus, the week time is (270 min.), as shown in table (5).

- The training program included physical preparation period of (1080 min.) by (40\%) , skillful preparation period of (945 min.) by (35\%), and tactical preparation period of (675 min.) by (25\%). Thus, the total time of the program as a whole including (2700 min.) as shown in table (5).

- The training program included elements of physical fitness which are developed through simple leading up games, where (20\%) for endurance with total time of (216 min.), (15\%) for strength with total time of (162 min.), (20\%) for agility with total time of (216 min.), (15\%) for speed with total time (162 min.), (30\%) for muscular power with total time of (324 min.), as shown in table (6).

- The training program included a set of simple leading 
up games to be applied in the physical preparation part accompanied by music to stimulate the players' motivation to produce the maximum possible energy and adding the factor of fun, pleasure, competition, suspense, and to remove the boredom and monotony that can be felt by the female players during training.

- The researcher selected the simple leading up games after reading the scientific researches and specialized references in the field of simple leading up games and mental disability and was classified in order to develop the elements of physical fitness of research (15), (10), (39), (33), (12), (16), (36), (37), (40), (4), (9), (28), (29), (27), (25), (30),appendix (3)

- The applied intensity in the training units was standardized through gradualism of load training, where wavelet method was used through intensity ranging from $(50 \%$ to $80 \%)$ of the maximum heart rate (M.H.R), where it can be calculated from the following equation:

Maximum heart rate $=220$ the age of the female player
(6), (34), (46), (39), (45), (7),

(6), (35), (38), (35), (41), (44) .

The following points were taken into account by the researcher in applying the simple leading up games:

(a) Simple leading up games are implemented gradually, from easy to difficult, and be applied in competitive way.

(b) Its objectives are to develop one or more elements of physical fitness.

(c) They should be associated with the performance of basic skills of basketball, as well as the movements of

female players

during performance.

(d) They should be proper to physical and skillful abilities of participants.

(e) Gradualism of load training through repetition of the game.

(f) Taking into account of security and safety when selecting and executing of the game (13), (12), (11), (6), (12), (21), (3), (16), (29), (25), (38), (27), (39).

- The training program consisted of basic skills drills of dribbling, shooting, passing, following up and defensive movement which were $(30 \%)$ for shooting with total time of 
(283,50 min.) , (20\%) for dribbling for total time of (189 min.), (20\%) for passing with total time of (189 min.), (15\%) for foot movements with total time of (141,75 min.), and $(15 \%)$ for following up with total time of (141.75 $\mathrm{min}$.), as shown in table (7).

Basic experiment:

The researcher conducted the basic experiment in the period from $6 / 11 / 2016$ to $6 / 2 / 2017$ through the following steps:

\section{a- Pre measurement} procedure:

The researcher conducted the pre measurement in the period 6/11/2016 - 10/11/2016 through the physical and skillful of research.

b- Application of the training program:

Presentation and discussion of the results:

1- Presentation of results:

Table (3)

Significance of differences between pre $\&$ post measurements in the physical and skillful variables of research $\mathrm{N}=12$

\begin{tabular}{|c|c|c|c|c|c|c|c|c|c|}
\hline \multirow[t]{2}{*}{ Variables } & \multirow{2}{*}{$\begin{array}{c}\text { Measuring } \\
\text { unit }\end{array}$} & \multicolumn{2}{|c|}{$\begin{array}{l}\text { Number } \\
\text { of ranks }\end{array}$} & \multicolumn{2}{|c|}{$\begin{array}{l}\text { Average } \\
\text { of ranks }\end{array}$} & \multicolumn{2}{|c|}{$\begin{array}{l}\text { Total } \\
\text { ranks }\end{array}$} & \multirow{2}{*}{$\begin{array}{c}\text { Values of } \\
\text { Calculated } \\
(\mathrm{Z})\end{array}$} & \multirow{2}{*}{$\begin{array}{c}\text { Level } \\
\text { of } \\
\text { sig. }\end{array}$} \\
\hline & & - & + & - & + & - & + & & \\
\hline Agility & sec. & 12 & zero & 6.5 & zero & $\overline{778}$ & zero & -3.061 & 0.002 \\
\hline Muscular power (arms) & meter & zero & 12 & zero & 6.5 & zero & 78 & -3.059 & 0.002 \\
\hline Muscular power (legs) & $\mathrm{cm}$. & zero & 12 & zero & 6.5 & zero & 78 & -3.089 & 0.002 \\
\hline $\begin{array}{l}\text { Muscular strength } \\
\text { (arms) }\end{array}$ & sec. & zero & 12 & zero & 6.5 & zero & 78 & -3.059 & 0.002 \\
\hline
\end{tabular}

Follow Table (3)
The researcher applied the training program in the period from $12 / 11 / 2016$ to $1 / 2 / 2017$ on the experimental research group through (10) weeks with (3) training units per week.

c- Post measurement procedure:

The researcher conducted the post measurement in the period $4 / 2 / 2017$ to $6 / 2 / 2017$ through the physical and skillful tests of research.

Statistical Processes:

The researcher used statistical processors through SPSS program including:

- Arithmetic mean (X), standard deviation (S.D), median, skewness coefficient, correlation coefficient (R), Wilcox signed-ranks and improvement percentage. 
Significance of differences between pre $\&$ post measurements in the physical and skillful variables of research $\mathrm{N}=12$

\begin{tabular}{|c|c|c|c|c|c|c|c|c|c|}
\hline \multirow[t]{2}{*}{ Variables } & \multirow{2}{*}{$\begin{array}{c}\text { Measuring } \\
\text { unit }\end{array}$} & \multicolumn{2}{|c|}{$\begin{array}{l}\text { Number } \\
\text { of ranks }\end{array}$} & \multicolumn{2}{|c|}{$\begin{array}{l}\text { Average } \\
\text { of ranks }\end{array}$} & \multicolumn{2}{|c|}{$\begin{array}{l}\text { Total } \\
\text { ranks }\end{array}$} & \multirow{2}{*}{$\begin{array}{c}\text { Values of } \\
\text { Calculated } \\
(\mathrm{Z})\end{array}$} & \multirow{2}{*}{$\begin{array}{c}\text { Level } \\
\text { of } \\
\text { sig. }\end{array}$} \\
\hline & & - & + & - & + & - & + & & \\
\hline $\begin{array}{ll}\begin{array}{l}\text { Muscular } \\
\text { (abdomen) }\end{array} & \text { strength } \\
\end{array}$ & number & zero & 12 & zero & 6.5 & zero & 78 & -3.078 & 0.002 \\
\hline Balance & sec. & zero & 12 & zero & 6.5 & zero & 78 & -3.061 & 0.002 \\
\hline Flexibility & $\mathrm{cm}$. & zero & 12 & zero & 6.5 & zero & 78 & -3.062 & 0.002 \\
\hline Endurance & sec. & 12 & zero & 6.5 & zero & 78 & zero & -3.059 & 0.002 \\
\hline Speed & sec. & 12 & zero & 6.5 & zero & 78 & zero & -3.061 & 0.002 \\
\hline Speed of dribbling & sec. & 12 & zero & 6.5 & zero & 78 & zero & -3.059 & 0.002 \\
\hline Shooting from different areas & points & zero & 12 & zero & 6.5 & zero & 78 & -3.088 & 0.002 \\
\hline Speed of passing & sec. & 12 & zero & 6.5 & zero & 78 & zero & -3.061 & 0.002 \\
\hline Defensive movements & number & zero & 12 & zero & 6.5 & zero & 78 & -3.109 & 0.002 \\
\hline
\end{tabular}
there are statistically significant differences between pre and post measurement of experimental group in the physical and skillful variables of research for post measurement, where

Table (4)

Percentage of improvement in physical and skillful variables of research $\mathrm{N}=12$

\begin{tabular}{|c|c|c|c|c|c|c|}
\hline \multirow{2}{*}{ Variables } & \multirow{2}{*}{$\begin{array}{c}\text { Measuring } \\
\text { unit }\end{array}$} & \multicolumn{2}{|c|}{ Pre Measurement } & \multicolumn{2}{|c|}{$\begin{array}{c}\text { Post } \\
\text { Measurement }\end{array}$} & \multirow{2}{*}{$\begin{array}{c}\text { Improvement } \\
\text { percentage } \\
(\%)\end{array}$} \\
\hline & & (X) 1 & $\begin{array}{c}\text { (S.D) } \\
1\end{array}$ & (X) 2 & $\begin{array}{c}\text { (S.D) } \\
2\end{array}$ & \\
\hline Agility & sec. & 15.768 & 0.208 & 12.688 & 0.389 & $24.36 \%$ \\
\hline Muscular power (arms) & meter & 10.608 & 0.370 & 14.076 & 0.762 & $32.71 \%$ \\
\hline Muscular power (legs) & $\mathrm{cm}$. & 111.750 & 2.958 & 124.667 & 3.172 & $11.57 \%$ \\
\hline Muscular strength (arms) & sec. & 5.887 & 0.272 & 10.762 & 0.531 & $83.07 \%$ \\
\hline $\begin{array}{ll}\begin{array}{l}\text { Muscular } \\
\text { (abdomen) }\end{array} & \text { strength } \\
\end{array}$ & number & 12.083 & 0.900 & 18,000 & 0.739 & $49.79 \%$ \\
\hline Balance & sec. & 13.233 & 0.879 & 22.270 & 1.990 & $68.43 \%$ \\
\hline Flexibility & $\mathrm{cm}$ & 10.007 & 0.215 & 13.691 & 0.507 & $36.80 \%$ \\
\hline
\end{tabular}

FollowTable (4)

Assiut Journal For Sport Science Arts 
Percentage of improvement in physical and skillful variables of research $\mathrm{N}=12$

\begin{tabular}{|c|c|c|c|c|c|c|}
\hline \multirow[b]{2}{*}{ Variables } & \multirow{2}{*}{$\begin{array}{c}\text { Measuring } \\
\text { unit }\end{array}$} & \multicolumn{2}{|c|}{ Pre Measurement } & \multicolumn{2}{|c|}{$\begin{array}{c}\text { Post } \\
\text { Measurement }\end{array}$} & \multirow{2}{*}{$\begin{array}{c}\text { Improvement } \\
\text { percentage } \\
(\%)\end{array}$} \\
\hline & & (X) 1 & $\begin{array}{c}\text { (S.D) } \\
1\end{array}$ & (X) 2 & $\begin{array}{c}\text { (S.D) } \\
2\end{array}$ & \\
\hline Endurance & sec. & 207.197 & 4.976 & 181.723 & 6.085 & $14.09 \%$ \\
\hline Speed & sec. & 17.030 & 0.242 & 13.404 & 0.615 & $27.24 \%$ \\
\hline Speed of dribbling & sec. & 13.942 & 0.129 & 11.003 & 0.439 & $26.87 \%$ \\
\hline $\begin{array}{l}\text { Shooting from different } \\
\text { areas }\end{array}$ & points & 3.833 & 0.835 & 6.583 & 1.621 & $71.81 \%$ \\
\hline Speed of passing & sec. & 20.164 & 0.614 & 15.802 & 0.546 & $27.66 \%$ \\
\hline Defensive movements & number & 7.583 & 0.793 & 11.583 & 0.900 & $53.77 \%$ \\
\hline
\end{tabular}

Table (4) shows that percentage of improvement in the physical and skillful tests of research to pre and post measurement ranged between $(11.57 \%-83.07 \%)$ for the post measurement.

\section{2- Discussion of results:}

Table (3) shows that there are statistically significant differences between pre and post measurements of experimental group in physical variables of research and that improvement, in view of researcher, was attributed to training program, which includes simple leading up games accompanied by music in the physical preparation part, where these games characterized by excitement and suspense which are full of fun and pleasure factors. So, the female players performed them eagerly without distress or boredom which led to development of physical fitness. This result is consistent with Amin Mustafa (1994), Ashraf Fekri (1997), Abeer Abu Rehab (1997), Zozo Hamed (1999), Amal Morsi (2002) who agreed that simple leading up games contribute significantly to the development of physical fitness. (33), (14), (4), (40), (10). Also, the researcher clarifies that selecting and arranging simple leading up games allow each game to develop one or more of physical fitness elements. Table (4) shows that the percentage improvement of pre and post measurements of physical fitness was for post measurement, where it was $(24.36 \%)$ for agility, and 
$(32,71 \%)$ for muscular power of the arms, (11.57\%) for muscular power of the legs, (83.07\%) for muscular strength of arms, (49.79\%) for muscular strength of the abdomen, $(68,43 \%)$ for balance, $(36,80 \%)$ for flexibility, $(14.09 \%)$ for endurance, and $(27,24 \%)$ for speed. It is clear from the above that the rate of improvement in some elements of physical fitness was higher significantly and that is due to, in point of view of researcher, regularity of female players in training, as well as the exerting possible maximum power performance by female players when applying the simple leading up games because of the excitement and suspense factors during performance accompanied by music. In this aspect, Wadih Yassin (2012) confirmed that simple leading up games contribute to development of physical fitness elements such as: speed, agility, endurance, flexibility, and speed of responsiveness, since the practitioner uses a large number of muscular groups, which lead to develop of their strengthening (39:38).

Also, Abeer Abu Rehab (1997) pointed out that simple leading up games accompanied by music avail an atmosphere of fun, excitement , competition and suspense when performance (4:28).

Both of Helmy Ibrahim \& Laila Farhat (1998) clarified that the individual with a disability who practices sports activity must use different stimuli such as: the rhythm of music and tools with dazzling colors as they help to active sensory perception and must be performed through simple leading up games that contribute to development of physical fitness (18:228).

Thus, the first hypothesis is achieved which stated, "there are statistical significant differences between pre and post measurement in some physical variables for educable mentally disabled for post measurement".

As for the improvement in the skillful variables, it is clear from table (3) that there are statistically significant differences between pre and post measurements of experimental group in skillful variables of dribbling, shooting, passing and 
defensive moving, where the improvement percentage between pre and post measurements was $(26.87 \%)$ for dribbling, $(71.81 \%)$ to shooting, $(27.66 \%)$ to passing, and $(53.77 \%) \quad$ defensive moving. The researcher is attributing that improvement to training program which was applied for (10) weeks, with (30) training units, in an scientific standardized method, where physical preparation part was applied through group of simple leading up games which were selected to develop physical fitness accompanied by music, in addition, the group of skillful drills of dribbling, shooting, passing , feet movements, and following up were standardized by gradual loads of intensity of training program ranged between $(50 \%$ to $80 \%)$ of maximum heart rate. Such an affair led to development of performances level of skills. Also, the contents of simple leading up games of movements, speeds, directed performance to motor trajectory of skills and development of various physical fitness elements, all contributed greatly to development of skillful variables of research. This result is consisted with the studies of Refai Mustafa (1992), Ashraf Fikri (1997), Abeer Abu Rehab (1997), Ibtisam Abdul Qadir (1999), Rehab Sheikh (2000), Emad Hamdy (2001), Munir Abdeen (2002), Elsayed Abu Nour (2004), Alaa Eddin Ibrahim (2005), Mohamed Badawi (2005), and Mohammed Hussein (2013) who agreed that simple leading up games contribute greatly to develop skillful performance level. As well as, these games are considered an important activity to the development of basic skills in various sports activities (37), (14), (4), (19), (36), (17), (30), (15), (8), (28). Amin El Khouly \& Jamal El Shafi (2009) confirmed that simple leading up games are considered the best games for mentally disabled, where they practice them according to their mental and skillful level, added to the nature of these games as an approach to disabled to acquire basic skills associated with the intended game. (12: 140) 
Thus, the second hypothesis is achieved which stated that "there are statistical significant differences between pre and post measurement in some skillful variables for educable mentally disabled for post measurement".

Conclusions

and

Recommendations:

Conclusions:

Within the limits of research objectives, its hypotheses, and sample, the researcher reached the following conclusions:

1- Simple leading up games have positive effect on some physical variables specified in agility, muscular strength, muscular power, balance, flexibility, endurance, and speed.

2. Simple leading up games accompanied by music have positive effect on some skillful variable of the dribbling, shooting, passing, and defensive movements.

3. The percentage of improvement between pre and post measurement in some physical and skillful variables was for post measurement.

\section{Recommendations:}

Based on the results that have been reached in this research, the researcher could recommend the following:

1- Including the simple leading up games accompanied by music in training programs for educable mentally disabled class.

2- Planners of training programs for educable mentally disabled should be attention to the simple leading up games accompanied by music in preparation of programs of various sport activities, and intellectual education schools.

3- Faculties of Physical Education should adopt the educable mentally disabled class in teaching and training courses and programs.

4- Organizing training courses for trainers by Egyptian Federation of Intellectual Disabilities to be aware of the new of that field.

5- Conducting similar studies in various activities to identify the effect of simple leading up games accompanied by music on development of basic skills for intended games and activities.

\section{References}


Arabic References:

1- Abdel-Azim, S. Mousa (1995): Vocational rehabilitati on for mentally retarded, Egyptian Renaissance Library, Cairo.

2- Abdo, S. Ibrahim (2005): Comparative study for training doses structures and their impact on level of physical and skillful performance for basketball players, unpublished Ph.D Thesis, Faculty of Physical Education, Tanta University.

3- Abdul Rahman, S. Suliman (2001): , Physical disability (concept, applications, therapeutic methods), Zahra El-shraf library, Cairo.

4- Abeer, H. Abu Rehab (1997): Effect of simple games accompanied by music on some physical qualities of handball in sports education lesson for preparatory stage female pupils, unpublished Master Thesis, Faculty of Physical Education, Port Said, Suez Canal University.

5- Adel, G. Abdulaziz (2007): The effectiveness of a specific training program on special physical abilities and level of some skillful performances of basketball players, unpublished Ph.D. Thesis, Faculty of Physical Education for Boys, Zagazig University. 6- Ahmed, A. Hussein (2010): A proposed program for learning basic skills in karate sport for individuals of simple mental disability, Master Thesis, Faculty of Physical Education , University of Banha.

7- Ahmed, M. Ibrahim (2015): Effectiveness of polymeric training in development of muscular power of legs and performance level to some basic skills for junior basketball, unpublished Master Thesis, Faculty of Physical Education, Banha University.

8- Alaa Eddin, I. Saleh (2005): Effectiveness of using leading up games to learn some skills of volleyball in the lesson of physical education, Journal of Sports Science and Arts, Volume 23, Faculty of Physical Education for Girls, Helwan University.

9- Alaa Eddin, M. Aliwa (2002): Photographic physical exercises, (individual, partner, group), on a form of simple games, First edition, Dar Bilal for Printing, El Mansoura. 
10- Amal, S. Morsy \& Mohammad, A. Mohammed (2000): Popular games and its impact on motor fitness and reduction of psychological loneliness feeling for mentally disabled children, Volume 3, Third Scientific Conference, Faculty of Physical Education for girls, El Gezira, Cairo.

11- Amal, M. Mahrous (2002): Proposal program to teach swimming basic skills for mentally disabled children and its impact on some motor abilities and psychological social aspects, Master Thesis, Faculty of Physical Education for girls, University .

12- Amin, A. Al-Khouli \& Gamal, E. El-Shafe (2009): Simple games and large games (conceptual and educational framework), Dar El fekr El Araby, Cairo.

13- Amir, M. Refaat (2012): The effectiveness of motor program associated with healthy guidance to improve physical and healthy efficiency for educable mentally disabled, unpublished Master Thesis, Faculty of Physical Education, Tanta University.

14- Ashraf, F. Rajh (1997): The impact of using leading up games on the development of some physical qualities and basic skills for junior soccer, Master Thesis , Faculty of Physical Education, Suez Canal University

15- El sayed, M. Abu El-Nour (2004): Effect of a program using leading up games on performance level to some basic skills of Hockey for Physical Education students, unpublished Master Thesis, Faculty of Physical Education, Mansoura University

16- Elaine, W. Faraj (1996): Experiences in games for children and adults, Monshat El Maarf, Alexandria.

17- Emad, H. Belidi (2001): Effect of using simple games to learn some basic motor skills for football game, Master Thesis, Faculty of Physical Education for Boys, Helwan University.

18- Helmi, M. Ibrahim \&Laila, E. Farhat: (1998), Physical Education and Recreation for Disabled, Dar El fekr El Araby, Cairo.

19- Ibtisam, A.Abdul Aziz (1999): Effect of proposed program using simple games on the development of some tennis skills for female junior from the age of (9-12) years, Master Thesis, Faculty 
of Physical Education for Girls, Helwan University.

20- Magda, S. Ibrahim : (2000), Effect of motor program using some of innovative tools on motor performance, personal and social adjustment for mentally disabled pupils, Volume 2 , the researches of third scientific conference, investment and human development in Arab world, Faculty of Physical Education for Boys, Cairo University.

21- Magdy, A. Ibrahim: (2003), Concept of education of special needs in light of their human, social and cognitive requirements, Anglo Egyptian Library, Cairo.

22- Mohamed, A. Moghazy (2010): Effect of developing some special physical abilities on the performance of some basic motor skills for mentally disabled (8-12 years), unpublished Master Thesis, Faculty of Physical Education for Boys, Alexandria University.

23- Mohamed, F. Soliman (2004): Effect of proposed recreational motor program on the development of basic skills for mentally disabled children
(6-12 years), unpublished Master Thesis, Faculty of Physical Education, Helwan University.

24- Mohamed, M. Abdel Dayem \& Mohamed, S. Hassanin (1984):

Measurement in basketball, Dar El fekr El Araby, Cairo.

25- Mohamed, M. Abu Zeid (2004): Effectiveness of a proposed program for simple games to improve life adjustment for mentally disabled, Master Thesis, Faculty of Physical Education for girls, Alexandria University.

\section{6- Mohamed, M. Fdaly} (1992): Sports for all, sports for all meeting, the Supreme Council for Youth and Sports, the Central Administration for Youth and Sports Researches, the series of scientific sports meetings, Cairo.

27- Mohamed, R. Ali (2005): Effect of training program using simple games during the period of special preparation on the effectiveness of the skilled performance for juniors wrestlers, unpublished Master Thesis, Faculty of Physical Education, Mansoura University. 
28- Mohammed, B. Hilal (2005): Simple games program accompanying by music and its impact on some basic natural movements for educable people with special needs, unpublished Master Thesis, Faculty of Physical Education, Tanta University.

29- Mohammed, H. Arfeek (2013): Educational program using leading up games in sports education lessons and its effect on learning some football skills for educable intellectual disabilities pupils, Scientific Journal, Volume 26, No.34, Benghazi University.

30- Mounir, M. Abdin (1995): The impact of leading up games on learning some offensive skills in basketball, Scientific Journal of Researches and Studies, Faculty of Physical Education Mansoura University.

31- Mustafa, F. Mohamed (1995): Psychology of abnormal children, Egypt Library, Cairo.

32- Nader, F. Zyoud (1995): Education of mentally retarded children, Dar El fekr for printing, publishing and distribution, Jordan.

33- Omnia, M. Shobokshi (1994): Effect of proposed simple games program on development of motor performance and general adjustment for mentally retarded pupils, Journal of Sports Science and Arts, Volume 6, Faculty of Physical Education for Girls, Cairo.

34- Osama, R. \& Ahmed, A. Amin (1998): Medical rules for the disabled sport, first edition, Saudi Arabia.

35- Osama, R. \& Nahed, A. Hamad (2001): Measurement and rehabilitation, Dar El fekr El Araby, Cairo.

36- Rehab, El-Sheik (2000): Effect of proposed program using leading up games to develop basic skills in basketball for preparatory school pupils, Master Thesis, Faculty of Physical Education for Girls, Helwan University, Cairo.

37- Rifai, M. Hassan (1992): Effect of proposed program of simple games on performance level to some basic skills for junior soccer, journal of Sports Education and Researches, part 2, Volume 21,22 , Zagazig University.

38- Taha, M. Abu El lel (2005): Physical education and sport for people with special needs, El Falah library, Beirut. 
39- Wadih, Y. El-Tikriti (2012): Handbook in simple games for all stages, Dar El Wafaa for printing and publishing, Alexandria.

40- Zozo, H. Hassan (1999): Effect of using proposal leading up program to learn basic skills and improve some motor abilities in handball for deaf and dumb, Magazine of Theories and Applications, Volume 34, Faculty of Physical Education for Boys, Alexandria University.

Foreign References:

41. David, G.: (1996), Development of Physical Education for days elementary school children, Macmillan Publishing Company, New York.

42. Futten, D.I.S: (1991), Effects of supplementary perceptual motor program on trainable mentally retarded children, L.D.A, Volume 4.

43. Katherine, R.: (1993), Sports program, effect on participants with mental retardation, A.B.S international Journal.

44. Nichols, B.: (1997), Moving and learning the elementary school physical Experience, Mosby Book, Inc. Saint Lewis, U.S.A.

45. Tan, D.M: (1991), Effect of minimally supervision exercises program for mentally retarded, Medicine and Science in Sports and Exercises.

46. Viviene, A. J.: (2003), Physical education for adolescents with mild in intellectual disabilities, Journal of Intellectual \& Development Disability, Volume 28, No.4. 